\title{
HUBUNGAN PENGUASAAN KALIMAT EFEKTIF TERHADAP KEMAMPUAN MENGANALISIS SURAT RESMI BERPERIHAL MAHASISWA PRODI PENDIDIKAN BAHASA INDONESIA SEMESTER V T.A. 2018/2019
}

\author{
Pontas J. Sitorus \\ Juni Agus Simaremare \\ FKIP Universitas HKBP Nommensen Medan \\ email: simaremarejuniagus@gmail.com
}

\begin{abstract}
This study aims to find out how "The Relationship of Effective Sentence Mastery Ability to the Ability to Analyze Official Letter of Subject by Students in the Indonesian Language and Literature Education Study Program Semester V T.A. 2018/2019 ". The method used in this study is a descriptive correlational method, which is a method or research technique that reveals clear facts about the symptoms and relationships that exist in an object of research. Data collection tools used are objective and subjective tests. Hypothesis testing is done by using the Product Moment correlation formula. From the results of correlation analysis between the ability to master effective sentences $(X)$ by analyzing letters with a letter $(Y)$, the coefficient price is 0.531 and after consultation with the $r$ table at a significant level of $95 \%$ (0.361) and at a significant level 99\% (0.463). Thus $r h>r t$ (0.588>0.361) and (0.588> 0.463), so the hypothesis states that there is a significant relationship between the ability to master effective sentences with the ability to analyze letters with a proven subject matter and work hypotheses accepted. This can be proven from the average ability of effective sentence mastery, namely 13 people (44\%) are in the medium category and 17 people (56\%) are in the high category while the ability to analyze the subject matter is high with 14 people (46\%) are in the medium category and 16 people (54\%) are in the high category. Based on the results of the correlation test it was found that the relationship between the ability to use conjunctions has sufficient correlation (by 0.588). So, there is a significant relationship between the ability to master effective sentences with the ability to analyze the subject matter by students of the Indonesian Language and Literature Education Study Program 2018/2019.
\end{abstract}

Keywords: Relationship, Ability, Effective Sentences, Official Letter of Subject

\begin{abstract}
Abstrak
Penelitian ini bertujuan untuk mengetahui bagaimana "Hubungan Kemampuan Penguasaan Kalimat Efektif terhadap Kemampuan Menganalisis Surat Resmi Berperihal oleh Mahasiswa Program Studi Pendidikan Bahasa dan Sastra Indonesia Semester V T.A. 2018/2019". Metode yang digunakan dalam penelitian ini adalah metode deskriptif korelasional, yaitu cara atau teknik penelitian yang mengungkapkan fakta yang jelas tentang gejala-gejala serta hubungan yang ada pada suatu objek penelitian. Alat pengumpulan data yang digunakan adalah tes objektif dan subjektif. Pengujian Hipotesis dilakukan dengan menggunakan rumus korelasi Product Moment Dari hasil analisis korelasi anatara kemampuan menguasai kalimat efektif $(X)$ dengan menganalisis surat berperihal $(Y)$ diperoleh harga koefisien 0,531 dan setelah dikonsultasikan dengan $r$ tabel pada taraf signifikan 95\% $(0,361)$ dan pada taraf signifikan 99\% (0,463). Dengan demikian $r h>r t$ (0,588>0,361) dan (0,588 > 0,463), sehingga hipotesis menyatakan terdapat hubungan yang signifikan antara kemampuan menguasai kalimat efektif dengan kemampuan menganalisis surat berperihal teruji kebenaranya dan hipotesis kerja diterima. Hal ini dapat dibuktikan dari rata-rata kemampuan penguasaan kalimat efektif yaitu 13 orang (44\%) berada pada kategori sedang
\end{abstract}


dan 17 orang (56\%) berada pada kategori tinggi sedangkan skor kemampuan menganalisis surat berperihal adalah tinggi dengan 14 orang (46\%) berada pada kategori sedang dan 16 orang (54\%) berada pada kategori tinggi. Berdasarkan hasil uji korelasi ditemukan bahwa hubungan kemampuan menggunkan kata penghubung memiliki korelasi yang cukup (sebesar 0,588). Jadi, ada hubungan yang signifikan antara kemampuan menguasai kalimat efektif dengan kemampuan menganalisis surat berperihal oleh Mahasiswa Prodi Pendidikan Bahasa dan Sastra Indonesia Tahun Pembelajaran 2018/2019.

Kata Kunci : Hubungan, Kemampuan, Kalimat Efektif, Surat Resmi Berperihal

\section{PENDAHULUAN}

Secara umum bahasa merupak sarana yang digunakan untuk dapat saling berkomunikasi, saling berbagi pengalaman, saling belajar dengan yang lain, dan mengingatkan kemampuan intelektual. Dengan demikian, fungsi utama bahasa ialah sebagai alat komunikasi dan sarana berpikir. Selain itu, bahasa merupakan alat yang dipakai untuk menyampaikan keinginan manusia maupun perasaan manusia yang dihadapi. Hal tersebut sejalan dengan pendapat Samsuri (1978: 4) yang mengatakan bahwa bahasa adalah alat yang dipakai untuk membentuk pikiran dan perasaan, keinginan dan perbuatan, alat yang dipakai untuk memengaruhi dan dipengaruhi, dan bahasa adalah dasar yang pertama-tama yang paling kuat pada masyarakat manusia.

$$
\text { Dalam penyampaian pikiran }
$$

melalui bahasa sebagai sarana komunikasinya baik secara lisan maupun secara tertulis masih ditemukan berbagai kesalahan tatabahasa. Kesalahan yang terjadi tidak memandang instansi, lembaga, komunitas, maupun organisasi, akan tetapi ditemukan dalam setiap sendi-sendi kehidupan.

Kesalahan-kesalahan tersebut dalam suatu tulisan merupakan salah satu wujud ketidaktaatan terhadap kaidahkaidah bahasa. Kerapian atau keteraturan suatu susunan kalimat dapat mewakili pola berpikir dan tingkat intelegensi penulisnya. Tulisan yang jelas dan terarah merupakan perwujudan berpikir logis. Oleh karena itu, susunan kalimat harus singkat, cermat, tepat, menggunakan kosakata, dan ejaan yang tepat agar mudah dipahami orang lain (Murad, 1985: 70).

Kesalahan tersebut juga disebabkan oleh kurangnya penguasaan diksi, pungtuasi, huruf dan dan penulisan kata. Uraian di atas memunculkan permasalahan tentang penggunaan bahasa Indonesia yang baik dan benar dalam surat tersebut. Apakah surat yang telah disusun tersebut sudah mengacu pada kaidah bahasa Indonesia, sehingga dapat dijadikan bahan pembelajaran untuk peningkatan kemampuan berbahasa indonesia baik secara lisan maupun tulis, terutama pada penulisan surat. Oleh karena itu, peneliti termotivasi mengkaji tentang analisis kesalahan bahasa surat, khususnya pada istansi/ badan atau perkantoran oleh peneliti terdahulu. Adapun peneliti yang relevan, sebelumnya yaitu: (1) Ramlah pada tahun 2004 dengan judul adalah "analisis kesalahan berbahasa Indonesia dalam karangan siswa kelas II SMA Negeri 1 Campalagian Kabupaten Polowali Mandar", (2) Herawati. B pada tahun 1999 yang berjudul "analisis kesalahan penggunaan bahasa pada papan reklame dan spanduk di kota Makassar", dan (3) Muhammad Akhir pada tahun 2007 dengan judul "analisis kesalahan berbahasa Indonesia dalam tesis Mahasiswa program pascasarjana Universitas Negeri Makassar". Jadi, dapat disimpulkan bahwa peneliti ini dengan peneliti sebelumnya tampak memiliki perbedaan.

Begitupun dengan peneliti, mengapa memilih judul tersebut, karena ada yang terkesan kepada peneliti yaitu setelah peneliti membaca sebuah surat, ternyata masih banyak kesalahan 
bahasanya terutama pada penggunaan ejaan, pilihan kata, dan kalimat.

Berdasarkan pernyataan tersebut di atas yang menjadi rumusan masalah dalam penelitian ini adalah Bagaimana kemampuan mahasiswa Program studi Pendidikan Bahasa dan Sastra Indonesia Semester V T.A. 2018/2019 menguasai kalimat efektif? Bagimana kemampuan mahasiswa Program studi Pendidikan Bahasa dan Sastra Indonesia Semester V T.A. 2018/2019 menganalisis surat resmi berperihal? Bagaimana hubungan penguasaan kalimat efektif terhadap kemampuan menganalisis surat resmi berperihal Mahasiswa Program studi Pendidikan Bahasa dan Sastra Indonesia Semester V T.A. 2018/2019?

Yang menjadi tujaun penelitian adalah untuk mengetahui kemampuan mahasiswa Program studi Pendidikan Bahasa dan Sastra Indonesia Semester V T.A. 2018/2019 menguasai kalimat efektif. Untuk mengetahui kemampuan mahasiswa Program studi Pendidikan Bahasa dan Sastra Indonesia Semester V T.A. 2018/2019 menganalisis surat resmi berperihal. Untuk mengetahui hubungan penguasaan kalimat efektif terhadap kemampuan menganalisis surat resmi berperihal Mahasiswa Program studi Pendidikan Bahasa dan Sastra Indonesia Semester V T.A. 2018/2019.

\section{LANDASAN TEORITIS \\ Hakikat Penguasaan Kalimat Efektif}

Penguasaan kalimat efektif adalah pemahaman atau kesanggupan penulis untuk menggunakan kalimat yang disusun berdasarkan kaidah-kaidah yang berlaku, seperti unsur-unsur penting yang harus dimiliki setiap kalimat (subjek dan predikat), memerhatikan ejaan yang disempurnakan, memilih kata (diksi) yang tepat dalam kalimat sehingga mudah dipahami oleh pembaca atau pendengar Kalimat efektif adalah kalimat yang dapat mewakili gagasan pembicara atau penulis serta dapat diterima maksudnya/arti serta tujuannya seperti yang di maksud penulis/pembicara. Rohmadi (2008: 92) mengatakan kalimat efektif adalah kalimat yang memperlihatkan bahwa proses penyampaian oleh pembicara atau penulis dan proses penerimaan oleh pendengar atau pembaca berlangsung dengan sempurna sehingga isi atau maksud yang disampaikan oleh pembicara atau penulis tergambar lengkap dalam pikiran pendengar atau pembaca. Kalimat yang baik harus memenuhi syarat gramatikal. Ini berarti kalimat itu harus disusun berdasarkan peraturan (kaidah yang berlaku). Kaidah-kaidah itu meliputi: unsurunsur kalimat yang penting yang ada dalam sebuah kalimat, penggunaan ejaan yang berlaku (EYD), dan cara memilih kata dalam kalimat. Konsep kalimat efektif menurut Abdul Razak (2004: 2) dikenal dalam hubungan fungsi kalimat selaku alat komunikasi. Setiap kalimat terlibat dalam proses penyampaian dan penerimaan. Apa yang disampaikan dan apa yang diterima itu mungkin berupa ide, gagasan, pesan, pengertian atau informasi. Kalimat dikatakan efektif bila mampu membuat proses penyampaian dan penerimaan itu berlangsung sempurna. Kalimat yang efektif mampu membuat isi atau maksud yang disampaikan itu tergambar lengkap dalam pikiran si penerima (pembaca), persis seperti apa yang disampaikan penulis. Sabarti Akhadiah (1996: 116) mengatakan bahwa kalimat efektif haruslah memiliki persyaratan gramatikal, disusun berdasarkan kaidah yang berlaku seperti: 1) unsur-unsur penting yang harus dimiliki setiap kalimat, 2) aturan tentang Ejaan Yang Disempurnakan, 3) cara memilih kata dalam kalimat (diksi). Kalimat efektif adalah kalimat yang benar dan jelas sehingga mudah dipahami orang lain secara tepat. Kalimat efektif harus memiliki kemampuan untuk menimbulkan kembali gagasan-gagasan pada pikiran pendengar atau pembaca seperti apa yang terdapat pada pikiran pembicara atau penulis. Hal ini berarti bahwa kalimat efektif haruslah disusun secara sadar untuk mencapai daya informasi yang diinginkan penulis terhadap pembacanya. Noerzisri A. Nazar (2006: 13) mengatakan bahwa kalimat efektif adalah kalimat dengan 
penggunaan jumlah yang sedikit dapat diungkapkan gagasan yang padat dan tepat tanpa terjadi pelanggaran terhadap kaidah setiap unsur dan aspek bahasa yang meliputi struktur kalimat, klausa, frasa, pilihan kata ataupun ejaan. Pada kalimat efektif unsur subjek dan predikat harus ada, sedangkan unsur lainnya harus ada jika dibutuhkan oleh penulis untuk kelengkapan pengungkapan ide atau gagasannya.

\section{Ciri-ciri Kalimat Efektif}

Kalimat dikatakan efektif jika memenuhi dua syarat utama yaitu, stuktur kalimat efektif dan ciri kalimat efektif. Struktur kalimat efektif meliputi kalimat umum yaitu kalimat minimal terdiri atas subjek dan predikat, kalimat paralel dengan penggunaan bentuk-bentuk bahasa yang sama yang dipakai dalam susunan serial. Struktur kalimat periodik dengan menampilkan keterangan sebelum bagian inti, dengan maksud menarik perhatian perhatian pembaca atau pendengar. Ciri kalimat efektif meliputi: 1) kesatuan (unity), bagaimana pun bentuk sebuah kalimat, baik kalimat inti maupun kalimat luas, agar tetap berkedudukan sebagai kalimat efektif, haruslah mengungkapkan ide pokok atau satu kesatuan pikiran. Kesatuan tersebut bisa dibentuk jika ada keselarasan antara subjek - predikat, predikat - objek, dan predikat keterangan. 2) Kehematan (economy), adalah hubungan jumlah kata yang digunakan dengan luasnya jangkauan makna yang diacu. 3) Penekanan (emphasis), adalah upaya pemberian aksentuasi, pementingan atau pemusatan perhatian pada salah satu unsur atau bagian kalimat, agar unsur atau bagian kalimat yang diberi penegasan itu lebih mendapat perhatian dari pendengar atau pembaca. 4) Variasi (variety), kelincahan dalam penulisan tergambar dalam struktur kalimat yang dipergunakan. Penulisan dengan pola kalimat yang sama akan membuat suasana monoton atau datar sehingga menimbulkan kebosanan pada pembaca. Kalimat panjang yang terus menerus dipakai akan membuat pembaca kehilangan pegangan akan ide pokok yang memungkinkan timbulnya kelelahan pada pembaca (Ida Bagus Putrayasa, 2007: 47). Sabarti Akhadiah (1996:116) mengatakan, agar kalimat dapat memberikan informasi kepada pembaca secara tepat seperti yang diharapkan oleh penulis, perlu diperhatikan beberapa hal yang merupakan ciri-ciri kalimat efektif sebagai berikut. 1) Kesepadanan dan kesatuan, artinya kalimat itu harus memiliki unsur-unsur subjek dan predikat, atau bisa ditambah dengan objek, keterangan, dan unsur-unsur subjek, predikat, objek, keterangan, dan pelengkap, melahirkan keterpaduan makna. 2) Kesejajaran (paralelisme), yaitu penggunaan bentukbentuk bahasa yang sama atau konstruksi bahasa yang sama atau konstruksi bahasa yang dipakai dalam susunan serial. 3) Penekanan dalam kalimat, setiap kalimat memiliki sebuah gagasan (ide) pokok. Inti pikiran ini biasanya ditekankan atau ditonjolkan oleh penulis atau pembicara.

\section{Struktur Kalimat Efektif}

Jan Fluitt-Dupuy (2006: 3)

mengatakan bahwa kalimat efektif memiliki dua struktur, yaitu struktur kalimat dan struktur kata. Stuktur kalimat merupakan bagian inti kalimat yaitu subjek dan predikat. Struktur kata (kata benda, kata sifat, kata depan) penyusun kalimat sederhana namun kompleks (padat). Menurut Ida Bagus Putrayasa (2007: 47) struktur kalimat efektif meliputi 1) struktur kalimat umum, unsur-unsur yang membangun sebuah kalimat dapat dibedakan menjadi unsur wajib dan takwajib (manasuka). Unsur wajib adalah unsur yang harus ada dalam sebuah kalimat (yaitu unsur subjek dan predikat). Sedangkan unsur tak wajib atau unsur manasuka adalah unsur yang boleh ada boleh tidak (yaitu kata kerja bantu, keterangan aspek, keterangan waktu tempat, dsb.). 2) Struktur kalimat paralel adalah penggunaan bentuk-bentuk bahasa yang sama dalam susunan serial. Jika sebuah ide kalimat dinyatakan dengan frasa, maka ide-ide yang sederajat harus dinyatakan dengan frasa. 3) struktur 
kalimat periodik, pada kalimat umum, unsur-unsur yang dikemukakan cenderung intinya, tetapi kalimat periodik, unsurunsur tambahan dikemukakan terlebih dahulu kemudian dimunculkan bagian intinya. Berdasarkan pendapat di atas dapat disimpulkan bahwa kalimat efektif mempunyai struktur yaitu struktur kalimat umum, paralel, dan periodik.

\section{Aspek-Aspek Pengukur Penguasaan Kalimat Efektif}

Herman J Waluyo (2007: 37) mengatakan kalimat efektif memiliki syarat: 1) memiliki kesepadanan: subjek, predikat, kata penghubung dalam dan antarkalimat, dan memiliki gagasan pokok. 2) memiliki kesejajaran/paralelisme: konstruksi bahasa dalam susunan serial. Misalnya dalam rincian, jika yang di depan kata kerja berawalan me- rincian selanjutnya juga berawalan me-. 3) Penekanan kalimat dalam kalimat, dengan ditandai pengulangan subjek kalimat, hiponimi, dan penggunaan kata secara tepat, (misalnya kata dari dan daripada). 4) Penggunaan variasi kalimat, yaitu dalam hal: letak, aktif-pasif, deduktif-induktif, dan panjang-pendeknya kalimat. Kalimat dikatakan efektif jika memenuhi dua syarat utama yaitu, stuktur kalimat efektif dan ciri kalimat efektif. Struktur kalimat efektif meliputi kalimat umum yaitu kalimat minimal terdiri atas subjek dan predikat, kalimat paralel dengan penggunaan bentuk-bentuk bahasa yang sama yang dipakai dalam susunan serial. Struktur kalimat periodik dengan menampilkan keterangan sebelum bagian inti, dengan maksud menarik perhatian perhatian pembaca atau pendengar. Menurut Ida Bagus Putrayasa ( 2007: 47) ciri kalimat efektif meliputi: 1) kesatuan (unity), bagaimana pun bentuk sebuah kalimat, baik kalimat inti maupun kalimat luas, agar tetap berkedudukan sebagai kalimat efektif, haruslah mengungkapkan ide pokok atau satu kesatuan pikiran. Kesatuan tersebut bisa dibentuk jika ada keselarasan antara subjek - predikat, predikat - objek, dan predikat - keterangan.

\section{Analisis Kesalahan}

Kesalahan berbahasa yang sering dibuat oleh penulis surat perlu diminimalkan. Hal ini baru dapat tercapai apabila seluk-beluk kesalahan berbahasa dikaji secara mendalam. Pengkajian segala aspek kesalahan itu adalah yang dimaksud analisis kesalahan (Tarigan, 1988: 67). Ada pakar pengajaran bahasa yang mengemukakan bahwa analisis kesalahan mempunyai langkah-langkah, yang meliputi: (1) pengumpulan sampel;(2) Pengidentifikasian kesalahan; penjelasan kesalahan; (4) pengklasifikasian kesalahan; dan (5) pengevaluasian kesalahan.

Menurut Tarigan (1988: 68), bahwa analisis kesalahan adalah suatu prosedur kerja yang biasa digunakan oleh peneliti dan guru bahasa Indonesia, yang terdiri atas: (a) pengumpulan sampel; (b) pengidentifikasian kesalahan yang terdapat dalam sampel; (c) penjelasan kesalahan; (d) pengklasifikasian kesalahan itu berdasarkan penyebabnya; dan (e) pengevaluasian atau penilaian taraf keseriusan kesalahan.

Dalam kamus linguistik dijelaskan "analisis kesalahan (error analysis) dalam pengajaran adalah teknik untuk mengukur kemampuan belajar bahasa dengan mencatat dan mengklasifikasikan kesalahan-kesalahan yang dibuat oleh seseorang atau kelompok" (Kridalaksana, 1984: 12).

Tarigan (1988: 69) mengemukakan bahwa tujuan analisis kesalahan, antara lain (1) menentukan urutan pengkajian butir-butir yang diajarkan dalam kelas dan buku teks, misalnya urutan mudah-sukar; (2) menentukan urutan jenjang relatif penekanan, penjelasan, dan latihan berbagai butir bahan yang diajarkan; (3) merencanakan latihan dan pengajaran remedial; dan (4) memilih butir-butir bagi pengujian dan kemahiran siswa.

\section{Pengertian Surat}

Surat merupakan alat komunikasi yang penting. Dalam surat, pesan atau buah pikiran penulis surat disampaikan dalam bahasa tulisan dan dikirimkan 
kepada penerima untuk mendapat tanggapan positif.

Dibandingkan dengan bahasa lisan, umumnya bahasa surat sebagai alat komunikasi secara tertulis relatif lebih singkat. Dalam menyusun surat harus dipertimbangkan baik-baik susunan kalimat, pilihan kata beserta artinya, dan perangkat ejaan serta situasi, karena semua hal tersebut sangat berpengaruh terhadap penyampaian maksud. Isi surat harus simpatik, sopan, luwes, tapi luas, menarik, sehingga penulis semestinya menghindari pemakaian kata yang kurang tepat, yang bermakna ganda, dan terutama yang dapat menyinggung perasaan penerima surat (Thomas Wyasa Bratawidjaja, 1988: 42).

Menurut (Hendry Guntur Tarigan, 1994) mengungkapkan bahwa ada empat komponen keterampilan berbahasa, yaitu:
(a) keterampilan menyimak,

keterampilan berbicara, (c) keterampilan membaca, dan (d) keterampilan menulis. Selanjutnya dikatakan setiap keterampilan itu erat pula berhubungan dengan prosesproses yang mendasari bahasa. Keterampilan hanya dapat diperoleh dan dikuasai dengan jalan praktek dan banyak latihan. Melatih keterampilan berbahasa berarti melatih pula keterampilan berpikir.

$$
\text { Surat adalah alat untuk }
$$

menyampaikan sesuatu maksud secara tertulis dari pihak yang satu ke pihak yang lain. Atau dapat pula dikatakan bahwa surat-menyurat merupakan satu kegiatan berbahasa yang dilakukan dengan komunikasi tertulis. Pihak-pihak yang tersangkut dalam kegiatan itu dapat berupa perseorangan atau badan (organisasi); sedangkan yang terlibat dalam kegitan ini adalah tiga unsur: penulis, isi surat, dan pembaca/ penerima surat (Bratawidjaja, 1988: 2).

\section{Syarat Surat yang Baik}

Surat sebagai sarana komunikasi tertulis, dalam penggunaan surat sebaiknya menggunakan bentuk yang menarik, tidak terlalu panjang, serta memakai bahasa yang jelas, padat, adab (etika dalam persuratan), dan takzim.
Hal-hal yang berhubungan dengan tata cara penyusunan surat itu harus diperhatikan benar-benar karena surat akan dibaca berulang-ulang atau diingat selama masih tertulis. Dengan demikian, hindari kata-kata yang kurang tepat, terutama yang menyinggung perasaan orang lain. Beberapa hal yang harus diperhatikan dalam menyusun surat sebagai berikut.

1. Alinea

Alinea adalah himpunan kalimat yang mengemukakan satu kesatuan pikiran untuk membentuk sebuah gagasan yang jelas. Dalam satu alinea, hanya ada satu pokok pikiran, tidak boleh lebih. Alinea yang sempurna terbentuk dari himpunan kalimat dan harus berkaitan dengan tema yang disampaikan. Namun demikian, ada juga alinea yang terdiri dari satu kalimat.

2. Kalimat

Kalimat adalah penyampaian makna tertulis. Dalam menyusun kalimat surat, hindari kesalahan penafsiran atau keraguan pada pihak pembaca

3. Diksi (tanda baca)

Ketepatan pilihan kata mempersoalkan kesanggupan sebuah kata untuk menimbulkan gagasan-gagasan yang tepat pada imajinasi pembaca atau pendengar, seperti apa yang dipikirkan atau dirasakan oleh penulis atau pembicara (Keraf, 1991: 87).

4. Ejaan dan Tanda Baca

Ketentuan penggunaan ejaan harus diperhatikan. Penggunaan ejaan yang benar sangat membantu pembaca dalam menafsirkan kalimat surat.

5. Penulisan huruf besar

Hal yang harus diperhatikan pada penulisan huruf besar dalam penulisan surat terutama untuk penulisan nama orang, nama jalan, kata ganti orang, nama lembaga, dan nama organisasi.

6. Penulisan kata turunan

Kata turunan adalah kata dasar yang diberikan pada imbuhan, sisipan, akhiran, dan gabungan imbuhan. Contoh, kata beri tahu jika berakhiran -kan menjadi beri tahukan, misalnya pada kalimat:

Dengan ini kami beri tahukan bahwa kata beri tahu jika mendapat gabungan imbuhan 
ditulis serangkai menjadi satu kata, yaitu memberitahukan, diberitahukan.

7. Penulisan kata ulang

Penulisan kata ulang ditandai dengan tanda hubung (-) terhadap unsur kata yang diulang, tidak boleh menggunakan angkaangka. Tujuan penulisan kata ulang adalah menyatakan penjamakan suatu kata dengan cara diulang bukan dengan cara menambahkan kata bilangan tidak tentu, seperti semua, segala, para, seluruh, beberapa, dan sebagainya. Contoh: barang diulang menjadi barang-barang bukan semua barang, semua barang-barang.

8.. Penulisan gabungan kata

Penulisan gabungan kata biasanya disatukan bila berupa kata majemuk dan ungkapan yang sudah dianggap senyawa.

9. Penulisan kata ganti

Penulisan kata ganti orang yang digunakan sebagai sapaan ditulis dengan huruf kapital.

10. Penulisan unsur serapan

11. Penggunaan tanda baca

Tanda baca harus digunakan secara tepat sebab jika tidak tepat menimbulkan arti yang berbeda.

\section{Penggunaan kalimat baku}

Kalimat adalah gugasan kata berstruktur atau bersistem yang mampu menimbulkan makna yang sempurna. Makna yang sempurna adalah suatu makna yang dapat diterima oleh orang lain sesuai dengan maksud yang dimiliki pembuat kalimat, (santoso, 1990: 127).

\section{Kerangka Pikir}

Dengan memperhatikan uraian pada tinjauan pustaka, maka pada bagian ini akan diuraikan beberapa hal yang dijadikan penulis sebagai landasan berpikir selanjutnya. Landasan berpikir yang dimaksud tersebut akan mengarahkan penulis untuk menemukan data dan informasi dalam penelitian ini guna memecahkan masalah yang telah dipaparkan untuk itu akan menguraikan secara rinci landasan berpikir yang dijadikan pegangan dalam penelitian ini, sebagai berikut:

1. Surat merupakan alat komunikasi yang penting. Dalam surat, pesan atau buah pikiran penulis surat disampaikan dalam bahasa tulisan dan dikirimkan kepada penerima untuk mendapat tanggapan positif.

2. Jenis-jenis surat

Adapun jenis-jenis surat pada tinjauan pustaka di atas yaitu:

a. Surat resmi yaitu surat yang biasanya digunakan dalam instansi-instansi resmi misalnya: pada bagian perkantoran ingin mengadakan suatu rapat pada instansi dan kepala kantor atau menejer tidak sempat meberi informasi secara lisan maka kepala kantor menulis surat kepada karyawan-karyawannya untuk menghadiri rapat tersebut.

b. Surat tidak resmi surat yang biasanya digunakan para anak-anak remaja yang pada dasarnya menulis surat kepada pacarnya atau kekasihnya karena merasa lama sekali tidak ketemu oleh sebab itu si remaja menulis surat untuk kekasihnya tersebut atau seorang anak rindu kepada orang tuanya yang jauh diseberang sana dan anak tidak sempat datang dan meluangkan waktunya karena sibuk dengan pekerjaannya (pelajarannya bagi mahasiswa/ pelajar) bigitu pun sebaliknya orang tua tidak bisa menemui anaknya yang di luar kota maka itu menulislah surat untuk melepas rasa kerinduannya itu.

\section{METODOLOGI PENELITIAN}

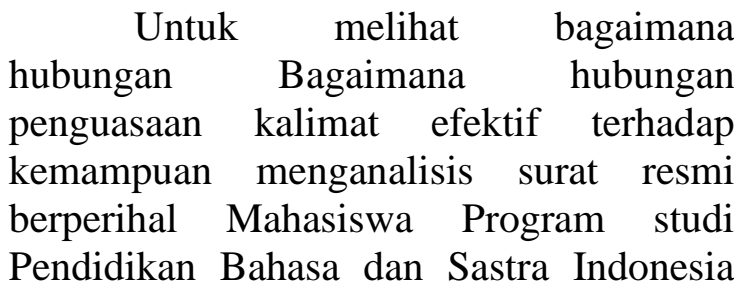
Semester T.A. 2018/2019, maka metode penelitian ini adalah metode deskriptif korelasional, yaitu untuk mengetahui bagaimana dengan Bagaimana hubungan penguasaan kalimat efektif terhadap kemampuan menganalisis surat resmi berperihal Mahasiswa Program studi Pendidikan Bahasa dan Sastra Indonesia T.A. 2018/2019 maka penelitian ini menggunakan metode deskriptif. Penelitian ini dilaksanakan di Universitas HKBP Nommensen Fakultas Keguruan dan Ilmu 
Pendidikan Program studi pendidikan bahasa Indonesia T.A. 2018/2019. Penelitian ini dilaksanakan pada semester ganjil tahun 2018/2019 mulai dari bulan Oktober sampai bulan Desember. Populasi dalam penelitian ini adalah seluruh Mahasiswa Program Studi Pendidikan Bahasa dan Sastra Indonesia T.A. 2018/2019.. Variabel penelitian adalah objek penelitian yang bervariasi." Penelitian ini terdiri dari dua variable, yaitu variable kemampuan penguasaan kalimat efektif (X) dan Kemampuan menganalis surat resmi berperihal (Y). Selanjutnya, Arikunto (2006:149) mengatakan, "Instrumen adalah alat pada waktu penelitian menggunakan suatu metode." Berdasarkan pendapat tersebut metode penelitian adalah instrumen tes. Alat pengumpulan data yang digunakan dalam penelitian ini adalah tes objektif (X) dan tes subjektif dalam variabel (Y). Jumlah soal yang digunakan untuk menjaring variable (X) adalah 20 soal. Untuk setiap jawaban yang benar diberi bobot skor (1) sedangkan jawaban yang salah diberi bobot (0). Sedangkang Jumlah soal yang digunakan untuk menjaring variabel (Y) adalah 30 soal.

\section{Uji Coba Instrumen}

Uji coba instrument dilakukan untuk mengetahui kesahihan (validitas), tingkat keterpercayaan (reliabilitas) alat ukur. Uji coba instrument tes dilakukan dalam dua tahap yaitu uji validitas dan uji reliabilitas.

\section{Uji Validitas Tes}

Uji validitas tes kemamampuan menggunakan kata penghubung dilakukan dengan menggunakan rumus product moment $\left(\mathrm{r}_{\mathrm{xy}}\right)$ sebagai berikut:

$\left(\mathrm{r}_{\mathrm{xy}}\right)$

$\frac{\mathrm{N} \Sigma \mathrm{XY}-(\Sigma \mathrm{X})(\Sigma \mathrm{Y})}{\sqrt{\left\{\left(\mathrm{N} \Sigma \mathrm{X}^{2}-(\Sigma \mathrm{X})^{2}\right\}\left\{\mathrm{N} \Sigma \mathrm{Y}^{2}-\left(\Sigma \mathrm{Y}^{2}\right)\right\}\right.}}$

Keterangan:

$$
\begin{aligned}
& \mathrm{N}=\text { Jumlah sampel yang } \\
& \text { diujicobakan } \\
& \Sigma \mathrm{X}=\text { Jumlah skor variabe } 1 \mathrm{X} \\
& \Sigma X^{2}=\text { Jumlah kuadrat skor variabel } \mathrm{X}
\end{aligned}
$$

$\Sigma \mathrm{Y}=$ Jumlah skor variabel $\mathrm{Y}$

$\Sigma Y^{2}=$ Jumlah kuadrat skor variabel $\mathrm{Y}$

$\Sigma \mathrm{XY}=$ Jumlah hasil perkalian $\mathrm{X}$ terhadap Y

\section{Uji Reliabilitas tes}

Untuk menentukan reliabilitas tes

dilakukan dengan menggunakan

perhitungan memakai rumus Kudder

Rieharsen (KR) 20 yaitu :

$r_{11}=\left(\frac{\mathrm{k}}{\mathrm{k}-1}\right)\left(\frac{\mathrm{Vt}-\Sigma \mathrm{pq}}{\mathrm{Vt}}\right) \quad$ (Arikunto,

$2006: 188)$

Keterangan :

$\mathrm{r}_{11}=$ reliabilitas Instrumen

$\mathrm{k}=$ banyaknya butir pertanyaan

$\mathrm{Vt}=$ variansi total proporsi subyek yang menjawab betul pada sesuatu butir (proporsi subjek yang mendapat skor 1

$\mathrm{p}=\frac{\text { Banyaknya subjek yang skornya } 1}{\mathrm{~N}}$

$\mathrm{q}=\frac{\text { Proporsi subjek yang mendapat skor } 0}{(\mathrm{q}=1-\mathrm{p})}$

\section{Teknik Analisis Data}

Teknik analisis data dilakukan dengan menggunakan langkah-langkah sebagai berikut:

1. Menentukan skor kemampuan menggunakan kata penghubung dalam kalimat dengan menghitung jawaban yang benar

2. Mengubah skor menjadi nilai akhir dengan cara jumlah jawaban yang benar dibagi jumlah soal dikali 100.

3. Menentukan skor kemampuan menyusun paragraf deduktif.

4. Mencari hubungan kemampuan menggunakan kata penghubung dengan kemampuan menyusun paragraf deduktif

5. Melakukan uji persyaratan Uji normalitas dan Uji linearitas

\section{Uji Persyaratan Analisis}

Penelitian ini bersifat korelasional (hubungan) yang bersifat parametrik, untuk itu data yang dikorelasikan harus memiliki dua syarat yaitu data berdistribusi normal dan antara variable $\mathrm{X}$ dengan variable $\mathrm{Y}$ menunjukkan gejala yang linear. Untuk itu dilakukan uji normalitas dan linearitas

a. Uji Normalitas

Uji normalitas dilakukan dengan menggunakan Rumus Chi kuadrat :

$$
X^{2}=\Sigma \frac{\left(f_{0}-f_{h}\right)^{2}}{f_{h}}
$$


Keterangan:

$\mathrm{X}^{2}=$ Chi kuadrat

$f_{o} \quad=$ Frekuensi Observasi

$f_{h}=$ Frekuensi harapan

Ketentuan yang d igunakan adalah

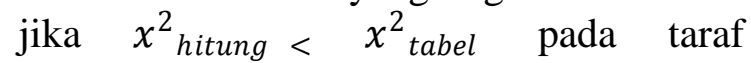
signifikan $5 \%$ dengan $\mathrm{db}=\mathrm{k}-1$, maka data penelitian berdistribusi normal.

b.Uji Linearitas

Uji linearitas dilakukan dengan menggunakan regresi $\mathrm{Y}=\mathrm{a}+\mathrm{bx}$.

Selanjutnya untuk menguji lineritas digunakan rumus :

$\mathrm{F}_{\mathrm{o}}=\frac{\mathrm{S}^{2}(\mathrm{TC})}{\mathrm{S}^{2}(\mathrm{~S})}$

Ketentuan yang digunakan adalah:

Jika $f_{\text {hitung }}<f_{\text {tabel }}$ pada taraf signifikan 5\% maka disimpulkan bahwa data penelitian adalah linier.

Melakukan Pengujian Hipotesis

Untuk mengetahui kebenaran hipotesis yang dirumuskan, maka digunakan rumus korelasi Product Moment $\left(\mathrm{r}_{\mathrm{xy}}\right)$ Rumus korelasi product moment dilakukan dengan menggunakan rumus angka kasar sebagai berikut :

$$
\begin{aligned}
& \mathrm{r}_{\mathrm{xy}}= \\
& \frac{\mathrm{N} \Sigma \mathrm{XY}-(\Sigma \mathrm{X})(\Sigma \mathrm{Y})}{\sqrt{\left\{\left(\mathrm{N} \Sigma \mathrm{X}^{2}-(\Sigma \mathrm{X})^{2}\right\}\left\{\mathrm{N} \Sigma \mathrm{Y}^{2}-\left(\Sigma \mathrm{Y}^{2}\right)\right\}\right.}} \\
& \text { Keterangan : } \\
& \mathrm{N} \text { = Jumlah subjek } \\
& \Sigma \mathrm{X}=\text { Jumlah skor variabel } \mathrm{X} \\
& \Sigma \mathrm{Y}=\text { Jumlah skor variabel } \mathrm{Y} \\
& \Sigma \mathrm{X}^{2}=\text { Jumlah kuadrat skor variabel } \mathrm{X} \\
& \Sigma Y^{2}=\text { Jumlah kuadrat skor variabel } \mathrm{Y} \\
& \Sigma X Y=\underset{Y}{\text { Jumlah hasil perkalian } \mathrm{X} \text { terhadap }} \\
& \text { Selanjutnya nilai } r_{\text {hitung akan }} \\
& \text { dikonsultasikan dengan harga } \\
& r_{\text {tabel }} \text { Error! Bookmark not defined. } \\
& \text { pada taraf } \\
& \text { signifikansi } 5 \% \text { atau } \alpha \quad 0,05 \text { dengan } \\
& \text { ketentuan : } \\
& \text {-Terima hipotesis kerja }\left(\mathrm{H}_{\mathrm{a}}\right) \text { jika } r_{\text {hitung }} \\
& \geq r_{\text {tabel }} \text { Error! Bookmark not defined. } \\
& \text {-Terima hipotesis nihil }\left(\mathrm{H}_{0}\right) \text { jika } r_{\text {hitung }}< \\
& r_{\text {tabel }} \text { Error! Bookmark not defined. }
\end{aligned}
$$

\section{HASIL PENELITIAN DAN PEMBAHASAN}

Dalam penelitian ini data yang diambil ada dua, yaitu data kemampuan penguasaan kalimat efektif (X) dengan kemampuan Menganalisis Surat Berperihal (Y). Berdasarkan pengolahan data akan diuraikan berturut-turut tentang deskripsi data, nilai rata-rata dan standar deviasi variable, pengujian persyaratan, dan pengujian hipotesis.

Perhitungan Rata-rata (M) dan Standar Deviasi (SD) data variabel Kemampuan Penguasaan Kalimat Efektif (X). Perhitungan rata-rata Kemampuan Penguasaan Kalimat Efektif dari 30 siswa yaitu $\mathrm{M}=78.5$. Sedangkan Perhitungan Standar Deviasinya adalah $\mathrm{SD}=7.25$. Sedangkan Perhitungan rata-rata $(\mathrm{M})$ dan Standar Deviasi (SD) kemampuan menganalisis surat berperihal (Y). Hasil Perhitungan rata-rata $(\mathrm{M}) \quad=77.6$ sedangkan hasil Perhitungan Standar Deviasi $(\mathrm{SD})=6.85$

\section{Uji Normalitas}

Salah satu persyaratan analisis yang harus dipenuhi agar dapat menggunakan statistik parametrik adalah sebaran data setiap variabel penelitian harus berdistribusi normal. Pengujian normal tidaknya sebaran data dilakukan dengan menggunakan rumus Chi kuadrat $\left(\boldsymbol{X}^{2}\right)$. Syarat normal dipenuhi apabila $\boldsymbol{X}^{\mathbf{2}} \boldsymbol{h}<\boldsymbol{X}^{\mathbf{2}}$ $\boldsymbol{t}$ pada taraf signifikan $\alpha: 5 \%$, dengan derajat kebebasan jumlah interval kelas dikurang satu. Dalam hal ini jumlah interval kelas adalah 6. Berdasarkan interval kelas kurva normal diperoleh derajat kebebasan (dk) :5 perhitungan selengkapnya ialah.

Tabel analisis menunjukkan bahwa uji normalitas variabel $X^{2} h=10,473$ dan data variabel $Y$ diperoleh $X^{2}=8,658$ dan setelah dikonsultasikan dengan $\mathrm{X}^{2}$ pada taraf $\alpha=0,05$ adalah 11,07, maka diperoleh $X^{2}<X^{2} t \quad(10,473<11,07)$. Dengan demikian dapat disimpulkan bahwa distribusi data dari kedua variabel penelitian adalah berdistribusi normal.

\section{Uji Validitas dan Reliabilitas Tes}

Dari hasil perhitungan dengan menggunakan rumus product moment dan dikonsultasikan dengan tabel harga kritik 
Product moment pada taraf signifikan 5\% dengan $\mathrm{N}=30$, yaitu 0,361 maka dapat diketahui bahwa $\boldsymbol{r}_{\text {hitung }}>\boldsymbol{r}_{\text {tabel }}(0,472$ $>0,361)$, maka butir soal nomor 1 termasuk soal yang valid.

\section{Reliabilitas Tes Kemampuan \\ Penguasaan Kalimat Efektif}

Untuk menentukan reliabilitas tes dilakukan dengan menggunakan perhitungan memakai rumus Kudder Rieharsen (KR) 20 yaitu :

$\boldsymbol{r}_{\mathbf{1 1}}=\left(\frac{\mathbf{k}}{\mathrm{k}-\mathbf{1}}\right)\left(\frac{\mathbf{V}_{\mathbf{t}}-\Sigma \mathbf{p q}}{\mathrm{Vt}}\right)$

Maka data yang diujicobakan diperoleh :

$$
\begin{aligned}
r_{11} & =\left(\frac{25}{25-1}\right)\left(\frac{24,13-5,8}{24,13}\right) \\
& =\frac{25}{24} \times \frac{18,33}{24,13} \\
& =1,04 \times 0,75=0,7904
\end{aligned}
$$

Sehingga didapat harga reliabilitas tes hasil belajar ini sebesar 0,7900. Setelah dikonsultasikan dengan indeks korelasi termasuk dalam kategori sangat tinggi.

\section{Uji Validitas Tes Kemampuan Menganalisis Surat Berperihal}

Uji validitas tes kemamampuan menganalisis surat berperihal dilakukan dengan menggunakan rumus product moment $\left(\boldsymbol{r}_{\boldsymbol{x} \boldsymbol{y}}\right)$ sebagai berikut:

Dari hasil perhitungan dan dikonsultasikan dengan tabel harga kritik Product moment pada taraf signifikan 5\% dengan $\mathrm{N}=30$, yaitu 0,361 maka dapat diketahui bahwa $\boldsymbol{r}_{\text {hitung }}>\boldsymbol{r}_{\text {tabel }}(0,619$ $>0,361)$, maka butir soal nomor 1 termasuk soal yang valid.

\section{Reliabilitas Tes Kemampuan Menganalisis Surat Berperihal}

Untuk menentukan reliabilitas tes dilakukan dengan menggunakan perhitungan memakai rumus Kudder Rieharsen (KR) 20 yaitu :

$r_{11}=\left(\frac{\mathrm{k}}{\mathrm{k}-1}\right)\left(\frac{\mathrm{V}_{\mathrm{t}}-\Sigma \mathrm{pq}}{\mathrm{Vt}}\right) \quad$ (Arikunto,

$2006: 188)$

$r_{11}=\left(\frac{25}{25-1}\right)\left(\frac{25,0-5,92}{25}\right)$

$$
\begin{aligned}
& =\frac{25}{24} \times \frac{19,08}{25} \\
& =1,04 \times 0,76=0,7904
\end{aligned}
$$

Sehingga didapat harga reliabilitas tes hasil belajar ini sebesar 0,7904 . Setelah dikonsultasikan dengan indeks korelasi termasuk dalam kategori sangat tinggi.

\section{Perhitungan Koefisien Korelasi Antar} Variabel

Untuk menghitung korelasi antara variabel penelitian digunakan rumus Product Moment angka kasar sebagai berikut :

$$
\begin{gathered}
\boldsymbol{r}_{\boldsymbol{x y}}= \\
\frac{\mathbf{N} \sum \mathbf{X Y}-\left(\sum \mathbf{X}\right)\left(\sum \mathbf{Y}\right)}{\sqrt{\left\{\left(\mathbf{N} \sum \mathbf{X}^{2}-\left(\sum \mathbf{X}\right)^{2}\right\}\left\{\mathbf{N} \sum \mathbf{Y}^{2}-\left(\sum \mathbf{Y}\right)^{2}\right\}\right.}}
\end{gathered}
$$

Perhitungan Koefisien Korelasi antara Kemampuan Menguasai Kalimat Efektif (X) dengan Kemampuan Menganalisis surat Berperihal (Y)

$$
\begin{aligned}
\mathrm{N} & =30 & \sum X^{2}=186475 \\
\sum \mathrm{X} & =2355 & \sum Y^{2}=182400 \\
\sum \mathrm{Y} & =2330 & \sum \mathrm{XY}=183800
\end{aligned}
$$

Dengan memasukkan harga-harga tersebut ke dalam rumus, maka diperoleh :

$$
\begin{aligned}
r_{x y} & =\frac{30.183800-(2355)(2330)}{\sqrt{\left\{\left(30.186475-(2355)^{2}\right\}\left\{30.182400-(2330)^{2}\right\}\right.}} \\
& =\frac{5514000-5487150}{\sqrt{\{(5594250-5546025\}\{5472000-5428900\}}} \\
& =\frac{26850}{\sqrt{\{48225\}\{43100\}}} \\
& =\frac{26850}{\sqrt{2078497500}} \\
& =\frac{26850}{45590,541}=0,588
\end{aligned}
$$

\section{Pengujian Hipotesis}

Dari hasil analisis korelasi anatara kemampuan menguasai kalimat efektif (X) dengan menganalisis surat berperihal (Y) diperoleh harga koefisien 0,531 dan setelah dikonsultasikan dengan $r$ tabel pada taraf signifikan $95 \%(0,361)$ dan pada taraf signifikan $99 \%(0,463)$. Dengan demikian rh > rt $(0,588>0,361)$ dan $(0,588>0,463)$, sehingga hipotesis menyatakan terdapat hubungan yang signifikan antara kemampuan menguasai kalimat efektif dengan kemampuan menganalisis surat 
berperihal teruji kebenaranya dan hipotesis kerja diterima.

Untuk menafsirkan arti koefisien yang diperoleh peneliti berpedoman pada pendapat Nurgiyantoro (1988 : 101) yang menyatakan :

“ $0,800-1,000=$ korelasi sangat tinggi

" $0,600-0,800=$ korelasi tinggi

“ $0,400-0,600=$ korelasi cukup

" $0,200-0,400=$ korelasi rendah

" $0.000-0,200=$ korelasi sangat rendah

Berdasarkan pendapat diatas dengan harga koefisien korelasi seebesar 0,588 dapat disimpulkan bahwa variabel dalam penelitian ini memiliki korelasi yang cukup

\section{Pembahasan Penelitian}

Berdasarkan hasil penelitian, penulis memperoleh gambaran bahwa hubungan kemampuan penguasaan kalimat efektif dengan kemampuan menganalisis surat berperihal mahasiswa Program Studi Pendidikan Bahasa Indonesia Tahun Pembelajaran 2018/2019 dapat dikategorikan tinggi.

Hal ini dapat dibuktikan dari ratarata kemampuan penguasaan kalimat efektif yaitu 13 orang (44\%) berada pada kategori sedang dan 17 orang (56\%) berada pada kategori tinggi sedangkan skor kemampuan menganalisis surat berperihal adalah tinggi dengan 14 orang (46\%) berada pada kategori sedang dan 16 orang $(54 \%)$ berada pada kategori tinggi. Berdasarkan hasil uji korelasi ditemukan bahwa hubungan kemampuan menggunkan kata penghubung memiliki korelasi yang cukup (sebesar 0,588). Jadi, ada hubungan yang signifikan antara kemampuan menguasai kalimat efektif dengan kemampuan menganalisis surat berperihal oleh Mahasiswa Prodi Pendidikan Bahasa dan Sastra Indonesia Tahun Pembelajaran 2018/2019.

\section{KESIMPULAN}

Berdasarkan hasil penelitian dan pembahasan, dapat kesimpulan sebagai berikut:

1. Kemampuan menguasai kalimat efektif mahasiswa program Studi Pendidikan Bahasa dan Sastra Indonesia Tahun
Pembelajaran 2018/2019 berada pada kategori tinggi (13 orang memiliki nilai sedang, dan 17 orang memiliki nilai tinggi).

2. Kemampuan menganalisis surat berperihal mahasiswa program Studi Pendidikan Bahasa dan Sastra Indonesia Tahun Pembelajaran 2018/2019 berada pada kategori tinggi (14 orang memiliki nilai sedang, 16 orang memiliki nilai tinggi)

3. Ada hubungan yang signifikan antara Kemampuan menguasai kalimat efektif dengan kemampuan menganalisis surat berperihal mahasiswa program Studi Pendidikan Bahasa dan Sastra Indonesia Tahun Pembelajaran 2018/2019. Hal ini diketahui dari uji hipotesis dengan $r_{\text {hitung }}>r_{\text {tabel }}$ baik taraf signifikan $5 \%$ maupun $1 \%$ yaitu $0,588>0,361$ dan $0,588>0,463$. Dapat disimpulkan bahwa hubungan Kemampuan menguasai kalimat efektif dengan kemampuan kemampuan menganalisis surat berperihal memiliki nilai korelasi yang cukup.

\section{DAFTAR PUSTAKA}

Abdul Chaer. 1990. Penggunaan Preposisi dan Konjungsi Bahasa Indonesia. Flores: Penerbit Nusa Indah . 1994. Linguistik Umum. Jakarta: PT. Rineka Cipta

Akhir, Muhammad. 1978. Analisis Kesalahan Berbahasa Indonesia dalam Tesis Mahasiswa Program Pascasarjana Universitas Negeri Makassar. Proposal. Makassar: PPs UNM.

Ambo Enre, Facruddin. 1994. Keterampilan Menulis I. Diktat. Ujung Pandang: FPBS IKIP.

Arifin, E. Zaenal. 1996. Penggunaan Bahasa Indonesia dalam Bahasa Surat. Jakarta: Akademika Pressindo. 
Arikunto, Suharsini. 1992. Prosedur Penelitian Suatu Pendekatan Praktis. Jakarta : Rineka Cipta.

Burhan, Nurgiyantoro. 1988. Penilaian dalam Pengajaran Bahasa dan Sastra. Yogyakarta : BPFE IKIP Yogyakarta

Bratawidjaja, Thomas Wiyasa. 1988. Surat Bisnis Modern. Jakarta: PT Pustaka Binaman Pressindo.

Departemen Pendidikan Nasional. 2006. Kurikulum Tingkat Satuan Pendidikan. Jakarta: Depdiknas

Departemen Pendidikan dan Kebudayaan RI. 1990. Kamus Besar Bahasa Indonesia. Jakarta: Depdikbud dan Balai Pustaka

Gorys, Keraf. 1991. Tatabahasa Indonesia . Flores : Penerbit Nusa Indah

Henry Guntur Tarigan. 1986. Menulis sebagai Suatu Keterampilan Berbahasa. Bandung : Penerbit Angkasa

Hastuti, Sri.1985. Permasalahan dalam Bahasa Indonesia. Cetakan kedua. PT Intan.

Herawati. 1999. Analisis Kesalahan Penggunaan Bahasa pada Papan Reklame dan Spanduk di Kota Makassar. Skripsi. Maksassar: FKIP UNISMUH.

Keraf, Gorys. Diksi dan Gaya Bahasa. Jakarta: PT Gramedia.

Kridalaksana, Harimurti. 1984. Kamus Linguistik. Edisi kedua. Jakarta: PT Gramedia.

M. Ramlan. 1987. Ilmu Bahasa Indonesia: Sintaksis. Edisi Revisi. Jogyakarta: C.V.Karyono
Moeliono, Anton. 1990. Kamus Umum Bahasa Indonesia. Jakarta: Balai Pustaka.

Pusat Pengembangan dan Pembinaan Bahasa Departemen Pendidikan dan Kebudayaan. 1988. Tata Bahasa Baku Bahasa Indonesia. Jakarta : PT. BalaiPustaka

. 1996 Pedoman Umum Ejaan Bahasa Indonesia yang Disempurnakan. Jakarta: Departemen Pendidikan dan Kebudayaan

Poerwadarminto, W.J. S., 1976. Kamus Besar Bahasa Indonesia. Jakarta: Bumi Balai Pustaka.

Panitia Pengembangan Bahasa Indonesia. 2004. Pedoman Pembentukan Istilah. Jakarta: Pusat Bahasa, Departemen Pendidikan Nasional.

Panitia Pengembangan Bahasa Indonesia. 2004. Pedoman Umum Ejaan Bahasa Indonesia Yang Disempurnakan. Jakarta: Pusat Bahasa, Departemen Pendidikan Nasional.

Pusat Pembinaan dan Pengembangan Bahasa. 1996. Bahan Penyuluhan Bahasa Indonesia. Jakarta: Pusat Pembinaan dan Penngembangan Bahasa Departemen Pendidikan dan Kebudayaan.

Ramlah. 2004. Analisis Kesalahan Berbahasa Indonesia dalam Karangan Siswa Kelas II SMA Negeri 1 Campalagian Kabupaten Polowali Mandar. Skripsi. Makassar: FKIP UNISMUH.

Rozanna, Cut dan Tedjaningsih. 1999. Surat Menyurat dan Komunikasi. Bandung: Angkasa. 
Rozanna, Cut, dkk. 1995. Surat Menyurat dan Komunikasi. Bandung: Angkasa.

Sitanggang, S.R.H.(Ed.) 2003. Anda Bertanya Kami Menjawab: Seputar Masalah Bahasa dan Sastra. Jakarta: Pusat Bahasa.

Sugono, Dendy. 1999. Berbahasa Indonesia dengan Benar. Jakarta: Puspa Suara

Sudjito \& Solchan TW. 1993. Surat Menyurat Resmi Bahasa Indonesia . Bandung :PT. Remaja Rosdakarya

Tarigan, Henry Guntur dan Djago Trigan. 1988. Pengajaran Analisis Kesalahan Berbahasa. Bandung: Angkasa.

Tarigan, Henry Guntur. 1993. Menulis Sebagai Suatu Keterampilan Berbahasa. Bandung: Angkasa.

Yatim, Riyanto. 2001. Metode Penelitian Pendidikan. Surabaya: Penerbit SIC 